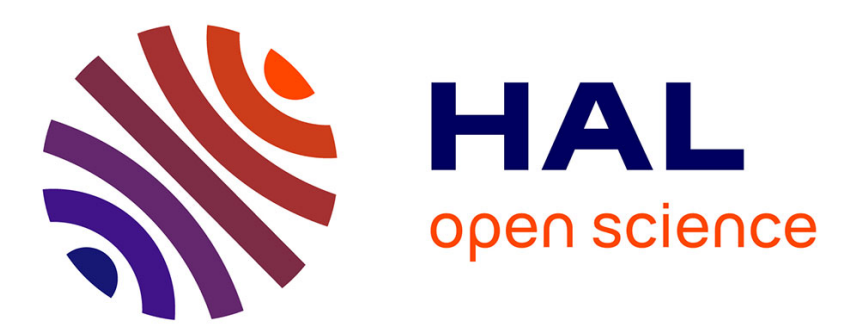

\title{
SMACKDOWN: Adventures in Simulation Standards and Interoperability
}

\author{
Priscilla Elfrey, Gregory Zacharewicz, Marcus Nie
}

\section{To cite this version:}

Priscilla Elfrey, Gregory Zacharewicz, Marcus Nie. SMACKDOWN: Adventures in Simulation Standards and Interoperability. Winter Simulation Conference WSC (2011), Dec 2011, Phoenix, United States. 10.1109/WSC.2011.6148086 . hal-00709305

\section{HAL Id: hal-00709305 \\ https://hal.science/hal-00709305}

Submitted on 19 Sep 2016

HAL is a multi-disciplinary open access archive for the deposit and dissemination of scientific research documents, whether they are published or not. The documents may come from teaching and research institutions in France or abroad, or from public or private research centers.
L'archive ouverte pluridisciplinaire HAL, est destinée au dépôt et à la diffusion de documents scientifiques de niveau recherche, publiés ou non, émanant des établissements d'enseignement et de recherche français ou étrangers, des laboratoires publics ou privés. 
Proceedings of the 2011 Winter Simulation Conference

S. Jain, R.R. Creasey, J. Himmelspach, K.P. White, and M. Fu, eds.

\title{
SMACKDOWN: ADVENTURES IN SIMULATION STANDARDS AND INTEROPERABILITY
}

\author{
Priscilla R. Elfrey \\ NASA \\ IT-C1, Kennedy Space Center \\ KSC, FL 32899, USA
}

\author{
Gregory Zacharewicz \\ Laboratoire IMS-LAPS CNRS \\ University of Bordeaux \\ France
}

\author{
Marcus Ni \\ Mechanical Engineering \\ University of Central Florida \\ Orlando, FL 32816, USA
}

\begin{abstract}
The paucity of existing employer-driven simulation education and the need for workers broadly trained in Modeling \& Simulation (M\&S) poses a critical need that the simulation community as a whole must address. This paper will describe how this need became an impetus for a new inter-university activity that allows students to learn about simulation by doing it. The event, called Smackdown, was demonstrated for the first time in April at the Spring Simulation Multi-conference. Smackdown is an adventure in international cooperation. Students and faculty took part from the US and Europe supported by IEEE/SISO standards, industry software and National Aeronautics and Space Administration (NASA) content of a resupply mission to the Moon. The developers see Smackdown providing all participants with a memorable, interactive, problem-solving experience, which can contribute, importantly to the workforce of the future. This is part of the larger need to increase undergraduate education in simulation and could be a prime candidate for senior design projects.
\end{abstract}

\section{M\&S EDUCATION: AN OVERVIEW}

As Modeling \& Simulation (M\&S) becomes increasingly important, there is a significant and growing need to educate, train, and certify M\&S practitioners, researchers, and faculty. Efforts to meet that need have taken a number of forms: academic degree programs, non-degree professional education, and professional certifications. In this context, academic degree refers to a bachelors, masters or Ph.D. programs, non-degree professional education refers to skills and knowledge attained for career advancement through facilitated learning, and professional certification refers to a designation earned to assure qualification to perform a job or task.

The lack of investment or planning energy does not mean that the government's senior M\&S leaders believe that a skilled workforce is not important. Increasingly everyone in workforce development perceives a persistent gap. The strategic priority, as identified by numerous stakeholders, is the need for a competent, seasoned, career government and industry workforce. They identified a number of obstacles in the path of achieving resolution of this gap and thus solving the long-term professional recruitment and M\&S career development issues:

- Some will say the problem begins in elementary or middle school with the lack of solid math, science, and engineering education that carries through to professional degree levels.

- A lack of standard M\&S curriculum content at all levels, particularly as an undergraduate major.

- Failure of the Department of Labor to recognize simulation as an industry and provide it with a unique career code.

- Absence of modeling and simulation on any serious list of critical technologies 


\section{Elfrey, Zacharewicz and $\mathrm{Ni}$}

\section{THE SMACKDOWN EXPERIENCE}

Regardless of the causes, conversations within the simulation community increasingly express concern about the sources for the next-generation of workers. While simulation grows as an industry, discipline and trans-disciplinary practice; academic programs to match this acceleration are scarce. A few schools offer specialties in modeling and simulation within engineering or computer science degree programs. It is hardly enough for a serious and fast-growing segment of the economy. Although more secondary schools are giving attention to modeling, simulation and related emerging technologies, only one university in this country, Old Dominion University, offers an undergraduate major.

This is troubling, especially, because simulation is proving to be a relatively recession-proof industry as health care, manufacturing, power, energy and education add to its traditional base of military training, science and space. Opportunities grow for those with experience. Getting into the field is the issue. The employment system and the market for modeling and simulation are similar in their inefficiency and ineffectiveness. One of the best ways for students to get jobs in preferred fields is to have experience which is difficult without a job. It is the old joke. Internships and cooperative education can help and such thinking was the impetus for an innovative employer-driven approach.

Zack Crues, a National Aeronautics and Space Administration (NASA) engineer suggested that the Simulation Interoperability Standards Organization (SISO) Space Community Forum put on an interuniversity event in which students learn about the importance of simulation interoperability by doing it and, in the process, become more employable and job-ready than the average college graduate. This met with support from industry, academia and government and proved to be ambitiously doable, satisfying and scalable undertaking.

Called Smackdown, this approach was demonstrated for the first time in Boston in April at the Spring Multiconference (Mc11). There were teams from the Massachusetts Institute of Technology, University of Alabama at Huntsville, Pennsylvania and North Carolina State Colleges (interns at Johnson Space Center) joined students from University of Bordeaux (France) and Genoa University (Italy).

The Smackdown experience was a virtual resupply mission to the Moon in which teams used the recently released SISO High Level Architecture (HLA1516 2010)-Evolved standards and industry software with NASA federates providing a spacecraft mission and the lunar environment. Teams had worked for months with the Smackdown technical and program teams at NASA's Kennedy Space Center, Johnson Space Center and with AEgis Technologies in Huntsville, Alabama. They, in turn, worked with the Executive, Industry and Outreach chairs handling issues as they arose, planning and creating a document repository.

The SISO provided students with access to its standards for HLA-Evolved. NASA developed the federates for the spacecraft, launch, mission and landing and take-off from the Moon, and including the lunar environment as well as technical and mentoring support. MÄK and Pitch Technologies provided students with HLA-Evolved Run Time Infrastructure (RTI) software, and Matlab and Simulink helped reduce the learning curve by proposing preprogrammed federates samples. In addition, ForwardSim developed and provided a realistic 3D visualization environment. Vendors gave the students advice and help with HLA and other software. This enabled students to work with the simulation systems to build and populate the Smackdown's 3D simulated environment in order for them to plan, experiment, test and demonstrate their work in the SISO Smackdown.

The NASA Student Intern Team modeled a lunar cargo delivery system to transport cargo (fuel, water, food and other consumables) to the lunar surface and to bring He-3, mined on the moon, from the lunar surface back to low lunar orbit. The NASA systems consist of a lunar orbit shuttle and a transport rover. The University of Bordeaux team, partnering with Genoa University, worked on the Earth Cargo Depot that stores objects for lunar surface use including parts, supplies, propellant, and oxygen arriving from the Earth Cargo. The joint team as well developed a intermediary Lunar Supply Depot federates to relay He-3, Moon rock to be transported back to earth, and other material between the landing site and the mining site.. The University of Alabama in Huntsville supplied a communications satellite orbiting the Moon. For this Smackdown event, UAH published, in particular, velocity and position as the satellite or- 


\section{Elfrey, Zacharewicz and $\mathrm{Ni}$}

bits the moon. The MIT team explored the concept of developing a fuel or resource economy for lunar space exploration. They developed a high-mobility scouting hopper to analyze resource concentrations at potential mining sites while a mobile In-Situ Resource utilization (ISRU) plant processes and transports resources to a depot for future use.

Using different tools, the first Smackdown in 2011 enabled students to move from one vendor product to another in a seamless mission that landed on the Moon, performed its tasks and took off for the return to Earth.

SISO in conjunction with NASA and industry will again host Smackdown in Orlando in April 2012. The organizers of this innovative STEM initiative anticipate participation from universities in the US, Europe, Near East, South America, New Zealand and Japan. As in 2011, student teams can create their own spacecraft, mission elements, subsystems, supply depots, rovers and communication satellites to orbit the Moon.

The organizers see particular value in the student team interaction with employers providing an opportunity to understand what is expected on the job and to have employers see what these students can do. The Executive, Outreach, and Industry are planning an enhanced approach to further bridge the gap between school and employment.

The KSC Center for Life Cycle Design's (CfLCD) summer intern team, Creative Humanics Laboratory (CHL) from Arizona State University and the Institute for American Indian Art (IAIA) in Santa Fe, New Mexico, is developing the Smackdown Starter Kit to enable academic teams anywhere to participate. The eight members of CHL augment the Smackdown with particular strengths in design, trouble shooting and system analysis as well as creative direction, film, storyboarding, animation, script writing, print media and engineering. CHL is developing graphic design interfaces, concepts and tools to enhance the Smackdown organizers in communicating the story to external resources and has plans for applying design skills to the Spring Smackdown.

Because the initial project showed the importance of students understanding and being familiar with simulation programming, the CHL team is taking a free-online JAVA program, from Stanford University discovered and tested earlier by a CfLCD undergraduate intern. This is being further validated by the CHL team for inclusion in the Smackdown Starter Kit and a follow-on proposal to the American Indian Higher Education Consortium (AIHEC) regarding incorporation of Smackdown into a proposal to incorporate other CHL projects including distributed simulation. The plan is to work with the Navajo Institute for Technology, the tribal college in Bismark, North Dakota and IAIA. NASA and AIHEC are also partnering on a major proposal for an undergraduate program to promote employability and job-readiness in modeling and simulation for the Tribal Colleges that will have Smackdown embedded in it as a key element.

The Smackdown experience evoked and continues to evoke, Neil Postman's comment in The End of Education: "Taking this point of view, we may conclude that science is not physics, biology, or chemistry--is not even a 'subject'--but a moral imperative drawn from a larger narrative whose purpose is to give perspective, balance, and humility to learning." (Postman 1996)

In terms of perspective: the learning focused particularly on the intersection between employer needs and student understanding of those needs. This illuminated both the present utility of simulation as a field of work and also the potential it promises for the future.

In terms of balance, the Smackdown enabled the teams - students and professionals - to address theory and practice, to see the relationship between what they learned and what simulation professionals do on the job. Smackdown balanced experience and analysis every step of the way.

In terms of humility, everybody learned more than they were taught. The teams held many telecoms with the technical team working out methods, learning to use the tools and testing the federates, but it was in coming together for the virtual mission that produced inspired problem solving, and dedicated team troubleshooting effort that paid off in a flawless virtual mission. In the review that followed at MIT everyone spoke of the inclusiveness of the experience and the value in working together internationally. We 


\section{Elfrey, Zacharewicz and $\mathrm{Ni}$}

have often said in NASA that it is easiest to work internationally in Space. Now, it seems, that such Space can be virtual.

\section{SUMMARY}

Smackdown is an adventure in international cooperation. It proves that standards and interoperability work. Students and faculty took part from the US and Europe supported by IEEE/SISO standards, industry software and NASA content of a resupply mission to the Moon. A team from KEIO University in Tokyo participated in the distributed development and testing, but had to withdraw after the terrible events in Japan. The developers see Smackdown providing all participants with a memorable, interactive, problem-solving experience which can contribute importantly to the workforce of the future. The US government, indeed the entire modeling and simulation community worldwide, needs a trained workforce with relevant skills and fully in tune with current and emerging objectives. This is essential to achieving an effective and efficient modeling and simulation capability.

\section{REFERENCES}

Blum, M., J, Busto, V. Chung, E. Crues, J. Hawkins, D. Dexter, D. Hasan and E. Jennings. 2008. "Integrating Collaborative Distributed Simulations for Space Exploration Missions". AIAA-2008-7089. In Proceedings of the AIAA Modeling and Simulation Technologies Conference, Honolulu, Hawaii.

Crues, E., M. Blum, V. Chung and J. Bowman. 2007. "The Distributed Space Exploration Simulation (DSES)," In Proceedings of the Spring 2007 Simulation Interoperability Workshop and Conference, Norfolk, Virginia, 25-30 March 2007.

Ni, M. 2011. KSC White Paper Evaluating Online JAVA Courses, May 2011.

Phillips, R., D. Dexter, and E. Crues. 2007. "A Coordinated Initialization Process for the Distributed Space Exploration Simulation (DSES)," In Proceedings of the Spring 2007 Simulation Interoperability Workshop and Conference, Norfolk, Virginia, 25-30 March 2007.

Postman, Neil. The End of Education, Vintage Books, New York, 1996

Vetter, K., and G. Hua. 2006. "The Trick User's Guide 2005.7.0 Release," NASA Technical Publication, NASA Johnson Space Center, June.

Vetter, K. 2006. "Trick Simulation Environment - User Training Material 2005.7.0 Release," NASA Technical Publication, NASA Johnson Space Center, June.

Szczerbicka, H., J. Banks, R. Rogers, T. Ören, H. Sarjoughian, and B. Zeigler. 2000. "Conceptions of curriculum for simulation education." In Proceedings of the 2000 Winter Simulation Conference, edited by J. A. Joines, R. R. Barton, K. Kang, and P. A. Fishwick, 1635-1644. Piscataway, New Jersey: Institute of Electrical and Electronic Engineers, Inc.

Yilmaz, L., P. Davis, P. Fishwick, X. Hu, J. Miller, M. Hybinette, T. Ören, P. Reynolds, H. Sarjoughian and A. Tolk. 2008. "What makes Good Research in Modeling and Simulation: Sustaining the Growth and Vitality of the M\&S Discipline." In Proceedings of the 2008 Winter Simulation Conference, edited by S. J. Mason, R. R. Hill, L. Mönch, O. Rose, T. Jefferson, and J. W. Fowler, 677-688. Piscataway, New Jersey: Institute of Electrical and Electronic Engineers, Inc.

\section{ACKNOWLEDGEMENT}

We would like to acknowledge contributions from Edwin Z. Crues, Daniel Dexter, Joseph Hubbard, William Waite, Alexia Joiner, Dannie Cutts, Danny Thomas, the Smackdown 2011 teams, faculty advisors and the KSC CHL20111 team. 


\section{Elfrey, Zacharewicz and $\mathrm{Ni}$}

\section{AUTHOR BIOGRAPHIES}

PRISCILLA R. ELFREY is the co-developer of the Kennedy Space Center (KSC) Center for Life Cycle Design. Educated at Barnard College, Columbia, NYU and Cornell School of Industrial and Labor Relations, she has over thirty years experience in organization and staff development, university administration, advanced aerospace technology, training, theater and visual media. In 1993, she initiated, was a founder and the project director of what is now the National Center for Simulation. She is the Smackdown Executive Committee Chair, and led the KSC CHL team. The author of The Hidden Agenda, published by John Wiley \& Sons, she is a member of SISO, SCS, Liophant and a Fellow of the McLeod Institute for Simulation Sciences in Savona, Italy. Her research contributions are in the areas of innovation, front end of design, workforce development, interactivity and communication. Her email address is < priscilla.r.elfrey@nasa.gov>.

GREGORY ZACHAREWICZ is Associate Professor at the University of Bordeaux and in the IMS UMR CNRS 5218 laboratory. His research interests include Discrete Event Modeling (e.g. DEVS, G-DEVS), Distributed Simulation, Distributed Synchronization Algorithms, HLA, FEDEP, MDA, Short lived Ontologies, BPMN and Workflow. He recently focused on Enterprise Modeling and Interoperability with applications to Logistics and Aeronautics. He has published several papers in M\&S Conference and International Journals. He is acting now as a frequent reviewer in M\&S conferences (Spring, Summer SCS, WinterSim ... ), Simulation and Logistics journals. He is involved in several French, European and Transatlantic founded projects. His email address is <gregory.zacharewicz@ubordeaux1.fr>.

MARCUS NI is a senior in mechanical engineering at the Univeristy of Central Florida who will be a coop student at KSC in the Spring of 2012. As a CfLCD intern at NASA KSC in Spring 2011, he engaged in the KSC DIVES research in visualization applied to Discrete Event Simulation data as well as producing STEM related research and projects including investigation of online JAVA simulation programming. 